\title{
EFFICIENT LEARNING FOR THE POOR: NEW INSIGHTS INTO LITERACY ACQUISITION FOR CHILDREN
}

\author{
HELEN ABADZI
}

\begin{abstract}
Reading depends on the speed of visual recognition and capacity of shortterm memory. To understand a sentence, the mind must read it fast enough to capture it within the limits of the short-term memory. This means that children must attain a minimum speed of fairly accurate reading to understand a passage. Learning to read involves "tricking" the brain into perceiving groups of letters as coherent words. This is achieved most efficiently by pairing small units consistently with sounds rather than learning entire words. To link the letters with sounds, explicit and extensive practice is needed; the more complex the spelling of a language, the more practice is necessary. However, schools of low-income students often waste instructional time and lack reading resources, so students cannot get sufficient practice to automatize reading and may remain illiterate for years. Lack of reading fluency in the early grades creates inefficiencies that affect the entire educational system. Neurocognitive research on reading points to benchmarks and monitoring indicators. All students should attain reading speeds of 45 60 words per minute by the end of grade 2 and $120-150$ words per minute for grades $6-8$.
\end{abstract}

Résumé - APPRENTISSAGE EFFICACE POUR LES PAUVRES : NOUVEAUX APERÇUS DE L'ACQUISITON DE L'ALPHABÉTISATION POUR LES ENFANTS - Lire dépend de la vitesse d'identification visuelle et de la capacité de la mémoire courte. Pour comprendre une phrase, l'esprit doit la lire assez rapidement pour s'en emparer dans les 12 secondes limites de la mémoire courte. Ceci signifie que les enfants doivent lire au moins 45-60 mots par minute pour comprendre un passage. La compréhension est étroitement liée à la vitesse et à l'exactitude de la lecture. Apprendre à lire implique "de duper" le cerveau pour qu'il perçoive des groupes de lettres comme étant des mots cohérents. Ceci est réalisé plus efficacement lorsqu'on accouple de manière consistante des petites unités à des sons que lorsqu'on apprend des mots entiers. Pour relier les lettres avec des sons, une pratique explicite et étendue est nécessaire ; plus épeler un langage est complexe, plus la pratique est nécessaire. CEPENDANT, les écoles des étudiants à faible revenu perdent souvent du temps et manquent de ressources, de sorte que les étudiants ne peuvent obtenir de pratique suffisante pour automatiser la lecture et demeurent analphabètes des années durant. Le manque de maîtrise des premiers niveaux crée des incapacités qui se répercutent à travers tout le système d'éducation. La recherche neurocognitive sur la lecture souligne les repères et les indicateurs de contrôle. Tous les étudiants devraient atteindre des vitesses de lecture de 45-60 mots par minute vers la fin du niveau 2 et 150 mots par minute vers la fin des niveaux 6-8.

Zusammenfassung - EFFIZIENTES LERNEN FÜR DIE ARMEN: NEUE ERKENNTNISSE IN DER ALPHABETISIERUNG VON KINDERN - Lesen hängt von der Geschwindigkeit des visuellen Erkennens und vom Fassungsvermögen des Kurzzeitgedächtnisses ab. Damit der Verstand einen Satz verstehen kann, muss er ihn schnell genug, nämlich innerhalb der 12-Sekundengrenze des Kurzzeitgedächtnisses 
erfassen. Das heisst dass Kinder mindestens 45-60 Wörter pro Minute lesen müssen, um eine Textpassage zu verstehen. Das Begriffsvermögen ist aufs Engste mit der Lesegeschwindigkeit und -genauigkeit verbunden. Beim Lesenlernen "überlistet" man gewissermaßen das Gehirn, Buchstabengruppen als zusammenhängende Worte wahrzunehmen. Dies erreicht man am effektivsten, indem man anstelle des Erlernens ganzer Worte kleine Einheiten gleichbleibend mit bestimmten Lauten verknüpft. Die Verknüpfung von Buchstaben mit Lauten bedarf allerdings regelmäßiger und gründlicher Übung; je komplexer die Rechtschreibung einer Sprache, umso intensiver muss geübt werden. Nun besteht aber an Schulen mit einkommensschwachen Schülern häufig ein Mangel an Ressourcen und relativ viel Zeitverschwendung, so dass die Schüler nicht genug Übung im automatisierten Lesen bekommen und auf Jahre hinaus Analphabeten bleiben. Mangelhafte Leseflüssigkeit in den ersten Klassen führt zu einer Inkompetenz, die sich durch das gesamte Bildungssystem hindurch fortsetzt. Die neurokognitive Leseforschung weist auf bestimmte Vergleichsmerkmale und Leistungsindikatoren hin. Alle Schüler sollten am Ende der zweiten Klasse eine Lesegeschwindigkeit von 45-60 Wörtern pro Minute erreicht haben und in den Klassen sechs bis acht über 150 Wörter pro Minute verfügen.

Resumen - APRENDIZAJE EFICIENTE PARA ALUMNOS DE ESCASOS RECURSOS: NUEVOS HALLAZGOS SOBRE CÓMO LOS NIÑOS ADQUIEREN LA LECTOESCRITURA. La lectura depende del reconocimiento visual y de la capacidad de la memoria a corto plazo. Para comprender una frase, la mente debe leerla con una velocidad suficiente para captarla dentro del límite de los 12 segundos de la memoria a corto plazo. Esto significa que los niños deben leer por lo menos 45 a 60 palabras por minuto para comprender un pasaje. La comprensión se relaciona en forma muy compleja con la velocidad y la precisión de la lectura. Aprender a leer implica "persuadir" a la mente a percibir grupos de letras como palabras coherentes. Esto se logra con mayor eficacia cuando se aparean en forma consistente pequeñas unidades con sonidos, más que cuando se aprenden palabras enteras. Para relacionar las letras con sonidos se necesita una práctica explícita y extensa, y cuanto más complejo sea el deletreo de un lenguaje, mayor será la práctica necesaria. Sin embargo, las escuelas con alumnos de bajos ingresos muchas veces pierden tiempo y no disponen de suficientes recursos, por lo cual los estudiantes no pueden recibir la práctica que necesitan para automatizar la lectura, y así pueden pasar años sin que superen el analfabetismo. La falta de fluidez en los primeros grados crea ineficiencias que pueden llegar a repercutir en todo el sistema educativo. La investigación neurocognitiva apunta a parámetros de comparación e indicadores de monitoreo. Todos los estudiantes deberían alcanzar velocidades de lectura de 45-60 palabras por minuto al finalizar el grado 2 y de 150 palabras por minuto en los grados 6-8.

\section{Резюме - ЭФФЕКТИВНОЕ ОБУЧЕНИЕ ДЛЯ МАЛООБЕСПЕЧЕННЫХ} ДЕТЕЙ: НОВЫЙ ВЗГЛЯД НА ПРОБЛЕМУ ГРАМОТНОСТИ - ЧтенИе завИсит от скорости визуального распознавания и объема кратковременной памяти. Для того чтобы понять предложение мозг должен прочитать его достаточно быстро, чтобы охватить его за 12-секундный интервал кратковременной памяти. Это означает, что дети должны прочитывать по меньшей мере 45-60 слов в минуту, чтобы понимать текст. Понимание тесно связано со скоростью и правильностью чтения. Обучение чтению включает такую «уловку», чтобы мозг воспринимал группы букв как связные слова. Наиболее эффективно это достигается путем последовательного соединения небольших 
частей слов со звуками, а не заучивания целых слов. Для того чтобы связать буквы со звуками, требуется много практики; чем более сложным является правописание языка, тем больше требуется практики. Тем не менее, школы для менее обеспеченных учащихся зачастую неэффективно расходуют время, им не хватает ресурсов, поэтому учащиеся не получают достаточно практики для того, чтобы автоматизировать навыки чтения, и остаются неграмотными на долгие годы. Отсутствие беглости в начальных классах создает препятствие, которое оказывает влияние на всю образовательную систему. Нейрокогнитивные исследования по чтению выявляют определенные критерии и контрольные показатели. Все учащиеся должны достигать скорости чтения 45-60 слов в минуту к концу второго класса и 150 слов в минуту в 6-8 клаccax.

\section{How psychology can inform education}

To alleviate poverty and provide basic skills to its largely illiterate population, the government of an African country solicited donor support and made large investments in primary education. Funds were used diligently to train and appoint teachers and administrators and to deliver textbooks to remote areas. As a result, gross enrollment rates in grades 1-5 increased from about $60 \%$ in 1992 to about $103 \%$ in 2005. However, learning outcomes remained alarmingly low, particularly among the poorer and rural students. An evaluation mission found that students were processing very little information. Teachers were often absent and, when present, spent little time in actual instruction. Primary school children spent much of their time copying from the blackboard but many were illiterate and could not decipher their own notes. Only about $25 \%$ of the initial cohort remained by grade 6 . There were no textbooks for secondary or higher education, so the survivors of primary education similarly spent much of their time engaged in copying or taking word-for-word dictation and had a poor understanding of mathematics or biology. Teacher training institutions offered general theories about education but did not focus on teaching of reading, in the official or in the national languages. The donor community expressed great concern about learning outcomes, but donor staff first had to deal with donor coordination complexities and high-level policies. Despite government commitment, the lack of knowledge about how low-income students can learn made it hard to provide quality education for all.

Studies conducted by the Independent Evaluation Group of the World Bank document poor learning outcomes worldwide (World Bank 2006). In countries such as Guinea, Mali, India, and Peru low-income students are often unable to read until the advanced primary grades (Education for All Global Monitoring Reports 2002-2006, Hanushek and Woessman 2007). 
For example, in francophone Guinea, only one out of 10 students knew the entire alphabet by the end of grade 2, and on average, students could read 4 of the 20 words presented (Spratt and Tamba 2005). Only 25\% of children in grade 1 and $45 \%$ of grade 2 children sampled in Peru were able to read a single word (Abadzi et al. 2005). Without fluent reading, students cannot learn from textbooks or respond reliably to standardized achievement tests. Poorer children fall behind in grade 1 and usually cannot catch up. Many may drop out illiterate. As a result, the percentages of those who attain mastery criteria, however set by various countries, are often in the single digits.

By enrolling thousands of poor children, schools must deal with a new clientele and do so with limited resources. But they lack knowledge and advice on how to help students learn under difficult and inefficient circumstances. Without such knowledge decision makers cannot set up programs that teach students efficiently, track the right indicators, or expect reasonable outcomes. But how to get up-to-date knowledge on improving the acquisition of basic skills and reading in particular?

The Independent Evaluation Group of the World Bank has found potential answers but also large obstacles (Abadzi 2006a, b). ${ }^{1}$ Academic publications about reading consist of two independent tracks that rarely intersect. Educators tend to focus on the effectiveness of various teaching methods, practical advice, and on theoretical considerations related to learning. Psychologists on the other hand tend to explore how the brain interprets and integrates information carried by print, given the functions of memory. This research domain often concerns the early stages of reading acquisition and could make important contributions to the education of the poor. However, transfer of this knowledge to educators has been limited. Colleges of education worldwide rarely if ever teach the basics of memory or the applications of cognitive neuroscience (Dempster 1988; Metcalfe 2006). To serve the poor better, the two tracks of research should be unified. This document constitutes an effort to explain in simple language the neuroscientific research in hopes of making it more accessible to educators (for greater detail see Abadzi 2006a, b, chapters 4-6).

\section{The mind's short-term timeframe and the need to read fast}

Very roughly, memory can be divided into short-term memory and long-term memory. Short-term memory (better known as working memory) holds the information that one is currently thinking of. Long-term memory stores information relatively permanently. Learning is like pouring information items into the biggest bottle in the world. People never run out of capacity to store knowledge in long-term memory. But the bottle has an extremely narrow neck; the short-term memory store can keep only about seven items of information for only about 12 seconds. ${ }^{2}$ To push large amounts information through the bottleneck, the brain chunks small items into larger pieces. This 
happens with practice and feedback. The smaller chunks are then connected into larger chunks like train cars hitched to form a railroad of fluent and automatic performance. Thus, the more sophisticated skills are based on highly practiced individual items.

Working memory is crucial for decision-making and integration of knowledge. The greater its capacity, the more efficiently people can use the data they receive in their everyday lives. Working memory capacity increases as children grow. Neural connections ("white matter") increase in the frontal lobes of the brain, and messages can be sent fast to various parts of the brain (Nagy et al. 2004). Its three components (central executive, phonological loop, and visuospatial sketchpad) may be immature or not communicate well at ages 4 or 5 , but they mature by age 6 (Korkman et al. 2001; Gathercole et al. 2004; Alloway et al. 2006). Working memory capacity peaks around the age of 20 and then gradually declines. Schooling lengthens working memory, and longer schooling is related to a larger capacity.

The most important implication of working memory capacity is that we are constantly performing in a very narrow timeframe of about 12 seconds. We must recognize letters and other items within a few milliseconds, otherwise we cannot hold the messages they convey in our minds long enough to interpret them or make decisions; by the end of a sentence we forget the beginning. Students cannot afford to read paragraphs letter by letter or get answers to math problems by counting on their fingers. Small items must be chunked. Higher-order skills emerge only after the very basic skills are practiced to the point of automatic and fluent performance.

\section{Literacy acquisition and the biology of reading}

Reading has a large biological component whose role is critical in the earliest stages of literacy acquisition. Middle-class children usually get the necessary practice at home or school and become fluent readers fast, so to some people this skill seems trivial. However, poor children may not get the same benefits. The complexities involved in reading acquisition may leave them illiterate for years.

The brain is not genetically set up for reading as it is for language, and the nervous system must become "programmed" for reading. Multiple circuits are involved in this process, some of which control the processing of fast-moving objects. The prerequisites are the following:

- Recognition of letters as objects, according to the brain's rules of visual recognition;

- Functional neural circuits that connect sounds to letter groups and link to word meanings;

- Sufficient knowledge of the patterns of a language to perceive separate sounds, syllables, words (phonological awareness); 
- Sufficient working memory available to hold a message long enough to make sense out of it; and

- Vocabulary knowledge for comprehension, context knowledge for interpretation

\section{Reading starts with the recognition of visual patterns}

Reading starts with tracking and interpreting individual letters in a morass of print. The brain must first isolate and recognize enough of the individual letters. Even proficient adults rely on single letters read in series to determine whether a chunk can be read as an entire word or can be inferred from context. An experiment showed that letters accounted for $62 \%$ of the adult reading rate, words for only $16 \%$, and context reading accounted for $22 \%$ (Pelli and Tillman 2007).

As mentioned above, people must hold in their working memory a message long enough to examine it and make sense of it. The phonological loop can only hold about 7 items for about 12 seconds, which means that a sentence of about seven words can be maintained for about 12 seconds. Some processing time is also needed for nerve transmissions. This capacity very roughly corresponds to one word per 1-1.5 seconds, or 45-60 words per minute. To avoid cluttering the working memory with failed attempts, people must also read accurately. A 5\% inaccuracy rate in reading is associated with comprehension test scores of only 75\% (Barr et al. 2002: 253). People who read more slowly or less accurately may be unable to keep an entire sentence in memory and thus may be functionally illiterate (Figure 1).

Brain imaging studies show three main areas involved in reading, two slower pathways and one for fluent reading (Figure 2; Shaywitz 2003: 76-87). Beginning readers use the slower pathways to link letters to sounds and decode words. One of them is near the speech area, and this creates the tendency to sound out subvocally a text in order to decode it. It is possible to read letter by letter, but processing in these two areas challenges the limits of the working memory. Novice readers who make conscious decisions about letters can only read small amounts of text and may have to read a message repeatedly to understand its meaning.

Fluency is achieved when an instant word recognition pathway is activated (in the left occipito-temporal region). This happens after much practice in pairing consistently sounds with groups of letters. Then an exact neural model of specific words is formed, reflecting spelling, pronunciation and meaning, and is permanently stored in the occipito-temporal system. This region responds very rapidly to any particular word (in less that 150 milliseconds) and sees it as a pattern. This is how reading is chunked and automatized. The added advantage is that automatic behaviors are not easily forgotten. Therefore, automatic readers do not normally lapse back into illiteracy. In some respects, reading fluency could be considered a vaccine against illiteracy. 
Figure 1. A general model of short-term (working) and long-term memory organization
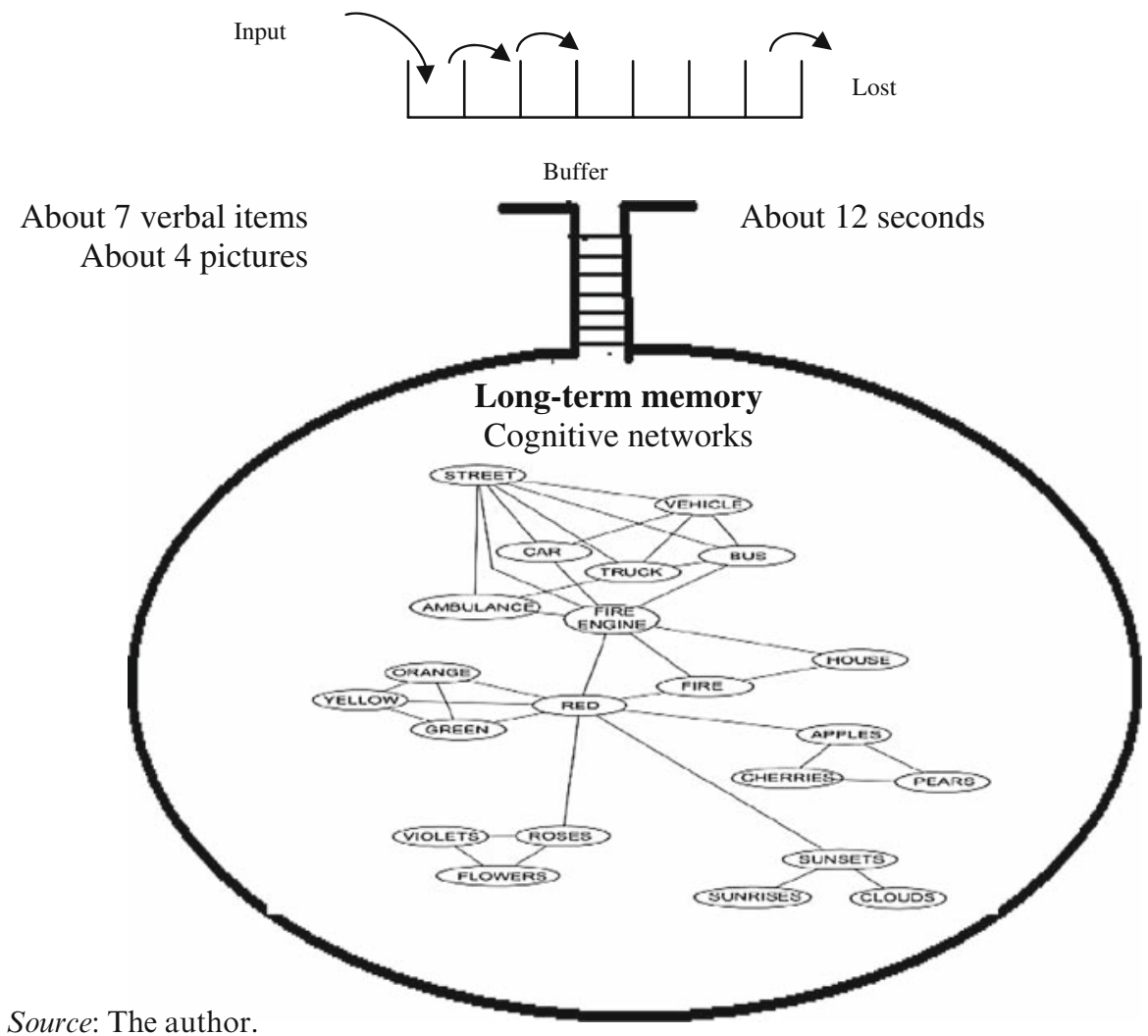

Source: The author.

Figure 2. Brain areas involved in slow and skilled reading.

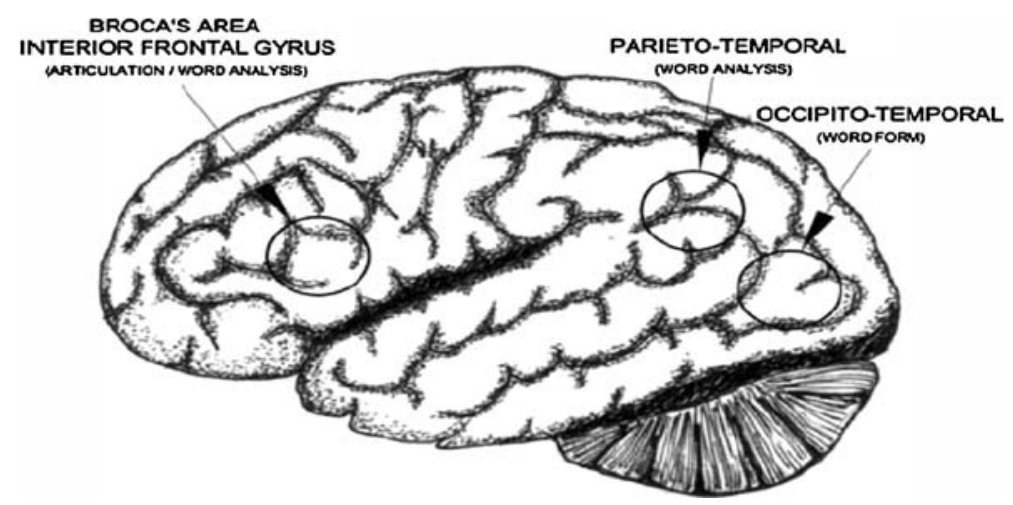

Source: Shaywitz 2003, pp. 78-82. 
Once the automatic pathway is activated, reading speed rises fast, and if the language is known, comprehension may follow suit. With sufficient practice, halting reading does not last long. The activation of the occipito-temporal pathway resembles the flipping of a switch to the "on" position. Proficient readers read effortlessly and anticipate what kind of text will come on a page. Looking at the left side of a page (or right side for Arabic and Hebrew), peripheral vision records outlying material. More recently seen and more frequent words are recognized faster, and errors are smoothed over without people noticing. People interpret the message from context and can make sense out of grossly misspelled words with missing letters.

Though it is possible to learn reading without knowing a language, ${ }^{3}$ good knowledge of the language of instruction is very helpful. This is because people identify letters faster if they are inside words than if they stand by themselves (a phenomenon called "word superiority effect"). Also readers have the benefit of context and can guess words they may not read fully. Therefore, students may benefit from learning to read in their mother tongue or one that they know well, even if they will rarely read in that language later. The use of little-understood languages may pose few problems when the spelling systems are transparent, but creates a major problem when they are complex (as in English, French, or Portuguese). Children must know the words in order to pronounce them. However, fluent reading in a language with simple spelling (such as Spanish or Tagalog) facilitates reading in a language with more complex spelling (such as English or French) when the same script is used (August et al. (2005) for Spanish, Ledesma and Morris 2005 for Tagalog, Cummins et al. 1984). For example, in a Ugandan reading sample, the correlation between reading speed in English and in a local language was found to be around 0.85 (Luis Crouch, Research Triangle Institute, personal communication).

The amount of practice required to activate the automatic pathway depends on the consistency between letters and sounds. The brain automatizes most efficiently the patterns that have clear correspondence between sound and letters. Consistent presentations of small patterns with specific sounds may make reading acquisition very efficient, while large patterns of multiple letters take longer to automatize. Most languages in the world are spelled regularly. When taught the sound-letter correspondences in reasonably good schools, children read common words fluently and quite accurately by the end of grade 1. Languages with simple spelling tax the working memory less and make it possible even for weaker students who rely on their slower reading pathways to make sense of the text (Wimmer et al. 1999). So, in the phonetically spelled European languages, middle-class children read basic text fluently before the end of grade 1 and may teach themselves to read in kindergarten. For example, Spanish and Italian children learn the basics in about three months and master coding skills almost perfectly by the end of the first grade (Harris and Hatano 1999: 17; Seymour et al. 2003). 
Figure 3. (a) and (b) Performance at the end of grade 1 in lists of very common words of various European languages.
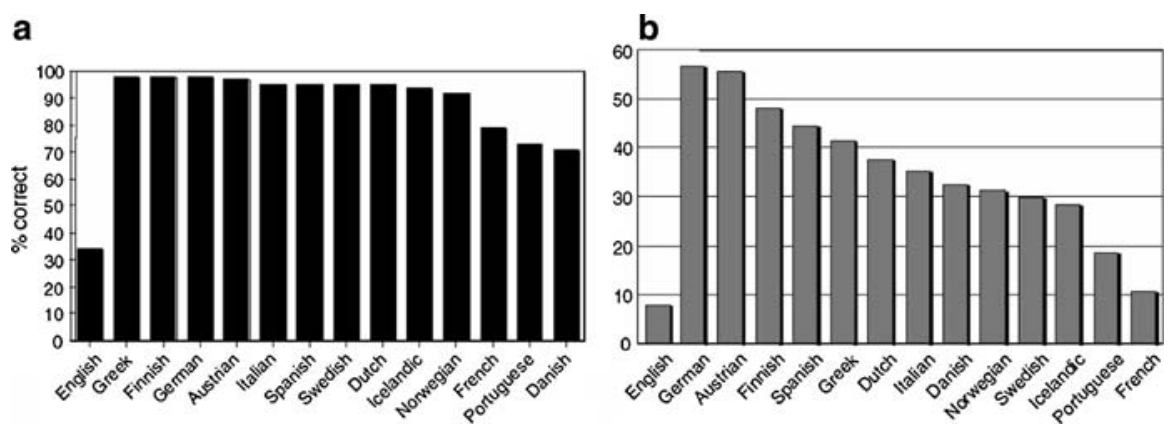

Source: Seymour et al. 2003; correlation between accuracy and speed was 0.87. (a) Lists of very common words, (b) Number of items read per minute.

When taught efficiently in languages with simple spelling, students progress in similar rates and show small individual differences (Figure 3(a) and (b)).

By contrast, in languages with complex spelling, rates of progress are slow, and individual differences are wide and persistent. Such languages require more practice for automaticity and also faster reading for timely comprehension. For example, a Portuguese-speaking child reading os mesmos, a gente, bom dia must understand the meaning at least partly and decide within milliseconds when to pronounce an $o$ as $u, d$ as $g$, or $t$ as $c h$. A French-speaking child must make similar choices, but they are more consistent, and first graders learn it as fast as Greek children when taught through phonics. Spelling in Denmark and Norway is more complex, but students are typically able to "crack the code" by the end of grade 1 and read fluently by the end of grade 2 (Hagtvet et al. 2005; Hagtvet and Lyster 1998, 2003). The irregularities of English present special problems, and children must learn lists of frequent words in early grades. Accuracy among 7-year old German children in grade 1 was $92 \%$ compared to $69 \%$ for Englishspeaking children (Wimmer 1999). Overall, English-medium students require 2.5 or more years of literacy learning to master the recognition of familiar words and simple decoding that is learned in one year for languages with simpler spelling rules (Seymour et al. 2003).

The interplay between speed and spelling complexity is particularly pertinent in Arabic and Hebrew. The Arabic script is consistent when vowels are used, but when they are omitted the readers must guess from context. In some countries like Morocco, the spoken language differs a lot from the written language, and children cannot easily guess from context. They must decipher without vowels the pronunciation of words that they do not know. 
Furthermore, unvoweled print makes extra demands on working memory. Students must learn very fast decoding early on in order to try out alternative meanings and make sense of the text. This task becomes particularly challenging in Farsi, Urdu and Pashto where vowels are not predictable as they are in Semitic languages. The deletion of vowels may be one reason for low reading outcomes in Arab countries. In all languages using this script, vowels should probably be maintained throughout primary school.

Another source of problems for students is the visual complexity of characters in certain languages. There is some evidence that more visually complex forms take longer to automatize than simpler forms (Pelli et al. 2006). For example, the syllabic Indian scripts are spelled consistently but have hundreds of combination symbols (e.g. 510 total in Kannada and about 300 in Tamil). Some are visually confusing, and students may have error rates of $60 \%$ in grade 2 , compared to virtually zero among students of simply spelled European languages (Nag 2003, 2007). Students also learn new combinations through primary school, though the most frequent ones are learned in the first one or two years. More research is needed on the visual perception issues of these scripts and on the simplification of reading instruction.

\section{Reading benchmarks and norms for grades 1-2}

Textbooks and curricula worldwide (usually formed for middle-class standards) expect reading fluency to be achieved in grades $1-2$, as in OECD countries. Fluency benchmarks exist in some countries, and they approximate the speed needed for the working memory to retain a sentence. A European cross-national study defined fluency as the reading speed of 2.25 seconds per word (27 words per minute), which children attain before the end of grade 1 (Seymour et al. 2003). In the United States, students tested in the spring read on average about 53 words per minute in grade 1 and 89 words per minute in grade 2 (Table 1; Hasbrouck and Tindal 2006). In Chile, the teacher-to-teacher network program of the Ministry of Education set goals for grades 1 and 2 at 30 and 70 words per minute, while the Chilean non-governmental organization (NGO) Educando Juntos has proposed goals

Table 1. US oral reading fluency norms - connected text - spring

\begin{tabular}{lccc}
\hline Grade & 50 th $\%$ ile & 25 th $\%$ ile & 10 th $\%$ ile \\
\hline 1 & 53 & 28 & 15 \\
2 & 89 & 61 & 31 \\
3 & 107 & 78 & 48 \\
4 & 123 & 98 & 72 \\
5 & 139 & 109 & 83 \\
6 & 150 & 122 & 93 \\
7 & 150 & 123 & 98 \\
8 & 151 & 124 & 97 \\
\hline
\end{tabular}

Source: Hasbrouck and Tindal (2006). 
around 34 and 64 words per minute for grades 1 and 2 respectively. ${ }^{4}$ A Cuban expert suggested 30 words per minute at the end of grade 1 as a reading speed for a "normal" child. (Perez Villar 1996). A study from Spain reported averages for the first and second grades about 50-55 and about 75 words per minute, respectively (Equipo de Orientación Educativa de Marbella 2003). Among the low-income Spanish-speakers in the U.S., a speed of just 30-60 words per minute in Spanish in Grades 1 and 2 is used as an index of disadvantage (de la Colina 2001). Similarly, a cutoff score of 40 words per minute places second graders in the U.S. at risk (Davidson and Towner 2005).

\section{Reading speeds for higher grades}

The minimum reading speed of 45-60 words per minute is suitable only for the processing of the simplest text. (The rate of 60 words corresponds to the 25th percentile of the US spring norms for grade 2-Table 1). More complex texts require faster reading so that the working memory can have enough time to process the meaning. This means that reading speed must rise with every grade, as is shown in Table 1, which pertains to U.S. data. The U.S. norms for higher grades (no other country study has been located) suggest that the average student should be reading at about 150 words per minute by grade 6 . If students lack textbooks or classroom time is not used well, they may read rarely, and speed may remain low. Then students may enter secondary school with insufficient fluency to read complex texts. For example, if students in grade 7 only read 80 words per minute, they may need 6 minutes to get through a single page of 500 words. Thus, they may be unable to keep up with the demands of their classes and drop out or develop behavior problems.

\section{Reading studies document low reading rates}

Following observations of illiterate low-income students by the Independent Evaluation Group and other researchers, several reading studies have been conducted to find how fast students read (mainly by the Research Triangle Institute of North Carolina, US). Many are still in process, and Table 2 presents preliminary data. The average students of lower-income countries fail to reach the 45 word-per-minute speed minimally needed for comprehension even in grades 3 or 4 . Also they gain too little from one grade to the next compared to US students, although the latter learn reading in a complex script. Also, variability is very large. In every country there are some high-performing schools and others that fail entirely to teach basic skills.

\section{The relationships between fluency and comprehension}

The relationship between reading speed and comprehension has been documented in the past (Laberge and Samuels 1974; Breznitz 1997a, b; Tan and Nicholson 1997), but educators typically know little about memory 
Table 2. Number of words read orally per minute

\begin{tabular}{|c|c|c|c|c|c|}
\hline \multirow[t]{2}{*}{ Country } & \multicolumn{4}{|l|}{ Grade } & \multirow[t]{2}{*}{ Total } \\
\hline & 1 & 2 & 3 & 4 & \\
\hline \multicolumn{6}{|l|}{ Senegal (semi-formal sample) } \\
\hline Grade-wise average & 2.9 & 17.4 & 32.4 & & 17.5 \\
\hline Grade-wise standard deviation & 5.9 & 17.4 & 23.5 & & 21.0 \\
\hline Average inter-grade gain & 14.8 & & & & \\
\hline \multicolumn{6}{|l|}{ The Gambia (formal sample) } \\
\hline Grade-wise average & 2.2 & 4.0 & 9.2 & & 5.1 \\
\hline Grade-wise standard deviation & 9.3 & 12.4 & 19.9 & & 14.8 \\
\hline Average inter-grade gain & 3.5 & & & & \\
\hline \multicolumn{6}{|l|}{ Jamaica (formal sample) } \\
\hline Grade-wise average & & 59.0 & 73.1 & & 66.1 \\
\hline Grade-wise standard deviation & & 46.8 & 48.1 & & 47.9 \\
\hline Average inter-grade gain & 14.1 & & & & \\
\hline \multicolumn{6}{|l|}{ Pakistan (formal sample) } \\
\hline Grade-wise average & 25.3 & 33.1 & 53.9 & 78.1 & 50.5 \\
\hline Grade-wise standard deviation & 30.5 & 34.4 & 39.2 & 46.5 & 43.2 \\
\hline Average inter-grade gain & 17.6 & & & & \\
\hline \multicolumn{6}{|c|}{ Peru (less formal sample, broadly representative) } \\
\hline Grade-wise average & 9.2 & 29.3 & & & \\
\hline Grade-wise standard deviation & 16.9 & 30.7 & & & 27.4 \\
\hline Average inter-grade gain & 20.1 & & & & \\
\hline \multicolumn{6}{|l|}{ Kenya (informal sample of schools) } \\
\hline Grade-wise average & 7.0 & 30.8 & 69.3 & 85.0 & 48.2 \\
\hline Grade-wise standard deviation & 15.0 & 39.0 & 79.3 & 68.9 & 64.0 \\
\hline Average inter-grade gain & 26.0 & & & & \\
\hline \multicolumn{6}{|c|}{ Kenya (formal representative sample in Malindi district) } \\
\hline Grade-wise average & & 11.4 & & & \\
\hline Grade-wise standard deviation & & 16.2 & & & \\
\hline Average inter-grade gain & NA & & & & \\
\hline
\end{tabular}

Source: Luis Crouch, Research Triangle Institute, publication in process.

mechanisms, so the rationale was not well understood. Recent educational research has also verified the predictions of memory research. For example, the correlation between speed and correct response to three simple questions was 0.82 in a reading study conducted in Peru (Abadzi et al.2005; Figure 4). A small study in Uganda (Crouch 2005, personal communication) showed correlations of 0.97 between reading speed and comprehension in the local language, and 0.87 in English. Another study involving the Dynamic Indicators of Basic Early Literacy Skills (DIBELS) battery of reading achievement showed that only the oral reading fluency subtest predicts comprehension, with vocabulary mediating the relationship (Riedel 2007).

Speed is necessary for comprehension but it is not sufficient. Vocabulary knowledge, inferences, comprehension of text structure and self-monitoring are important for spoken and written communication, and explicit instruction is needed in these skills. The correlations shown above have been produced 
Figure 4. Relationship between speed and number of questions answered.

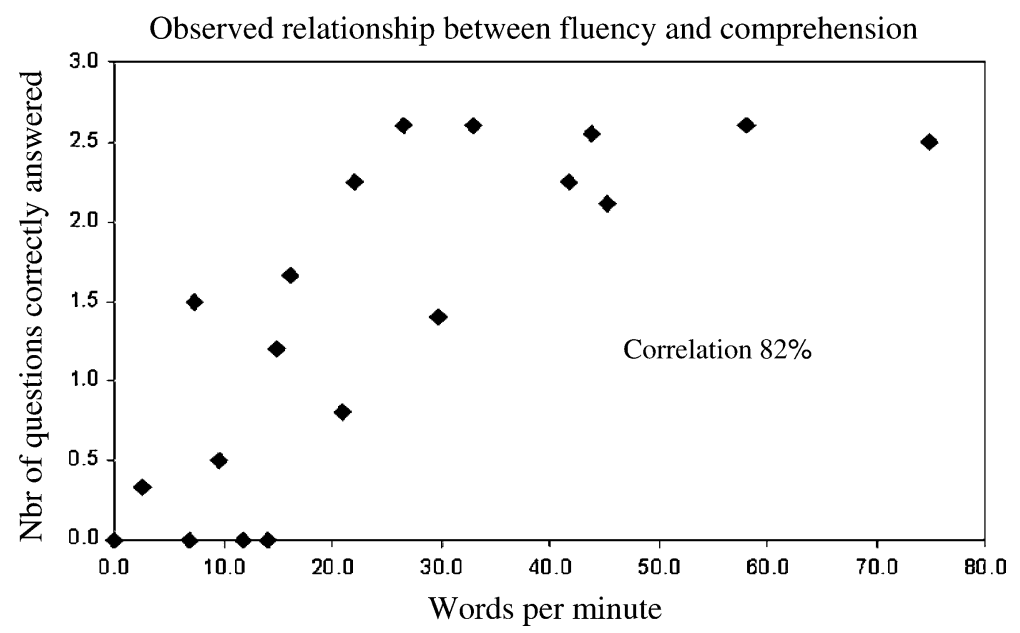

Source: Abadzi et al. 2005 Peruvian data.

with very simple material and fact-oriented questions; complex texts are likely to show more complex relationships, with prior knowledge being significant. But working memory seems to be the only gateway to comprehension. As the biology of reading is understood at this time, it is essentially impossible to read haltingly and comprehend much material.

In efforts to teach students meaningful material and facilitate comprehension, many educators emphasize the development of comprehension early on, so in literacy instruction, comprehension is often emphasized over fluency. Thus, schools in countries such as Brazil assign instruct students to produce and analyze texts while they are still illiterate. This is certainly desirable if instructional time is sufficient and is used well, so that students can become fluent readers by the end of grade 2 . However, in low-income schools, where time is wasted in absenteeism and other problems, students become illiterate artists, and one sees fourth graders surrounded by books that they cannot read. Early emphasis on comprehension for children who cannot get outside help may be putting the cart before the horse. Although it sounds counterintuitive, it may be better to focus on fluency early on and focus more on comprehension after students become fluent and their working memory capacity increases.

\section{Why is phonics instruction important?}

The controversy on the choice of phonics vs. the whole-word approach for reading instruction has led to "reading wars", particularly in the 
English-speaking world. Many teachers are attracted to the whole-word approach because they are interested in innovations and want to make classes interesting. The time-honored method of combining letters and syllables has been dismissed as boring and mechanistic, and some reading specialists have derided fluency practice as "barking at print". However, perceptual psychology and neuroimaging research have vindicated synthetic phonics. One reason concerns people's tendency to read by identifying individual letters about $62 \%$ of the time. Under these circumstances, the whole-word methods may prepare the students to deal with instant word identification that takes up only $16 \%$ of of readers' time (Pelli and Tilman 2007). Also, neuroimaging research has shown a "dual route" model of learning, where people learn to read small units on the basis of rules but also store entire words that are unusual (Norton et al. 2007). In addition, there is considerable educational evidence also against the whole word approach (particularly for the poor students; see Abadzi 2006a, b: 45-47 for a review).

Many studies have shown that teachers are not familiar with the required linguistic knowledge necessary to teach reading and spelling: locating or giving examples of phonic, syllabic, and morphemic units as well as analyzing words into speech sounds, syllables, and morphemes. However, when teachers were trained in explicit instruction in the linguistic knowledge and applied such knowledge to their instructional practices, their students performed better on reading tasks (McCutchen et al. 2002; McCutchen and Berninger 1999; Moats and Foorman 2003; Spear-Swerling and Brucker 2004). Of particular utility seems to be instruction in analogies that explicitly teach students the rules of spelling in each language. For example, the Indian NGO Pratham uses systematic instruction of analogies to increase poor students' performance in 45 school days (about six weeks), in sessions of two hours per day for reading and one for arithmetic (Table 3).

Students do not have to remain illiterate for years. Rigorous interventions have been found to increase students' speed and comprehension significantly in a matter of weeks (de la Colina et al. 2001; Banerji et al. 2004). No research has been found that estimates how many hours of practice are

Table 3. Instruction in systematic vowel-consonant combinations of various alphabets

\begin{tabular}{|c|c|c|c|c|c|c|c|c|c|}
\hline & $\mathbf{a}$ & e & $\mathbf{i}$ & $\mathbf{0}$ & $\mathbf{u}$ & Letter & Fatha & Qasra & Dhamma \\
\hline & & & & & & ض & ضَ & رِض & ضُ \\
\hline B & ba & be & bi & bo & bu & ص & صَ & صِ & صُص \\
\hline $\mathrm{C}$ & $\mathrm{ca}$ & ce & ci & co & $\mathrm{cu}$ & ث & ثَ & 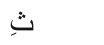 & ث \\
\hline D & $\mathrm{da}$ & de & de & do & $\mathrm{du}$ & ق & قَق & قق & قُ \\
\hline $\mathrm{F}$ & $\mathrm{fa}$ & $\mathrm{fe}$ & $\mathrm{fi}$ & fo & fu & د & د & $د$ & s \\
\hline G & $\mathrm{ga}$ & ge & gi & go & $\mathrm{gu}$ & ش ش & شَ & ش ش & شُ \\
\hline $\begin{array}{l}\mathrm{H} \\
\text { Etc }\end{array}$ & ha & he & hi & ho & hu & $\begin{array}{l}\text { سtc } \\
\text { Etc }\end{array}$ & سَس & س س س & 'س س \\
\hline
\end{tabular}


Figure 5. Instruction in systematic vowel-consonant combinations.

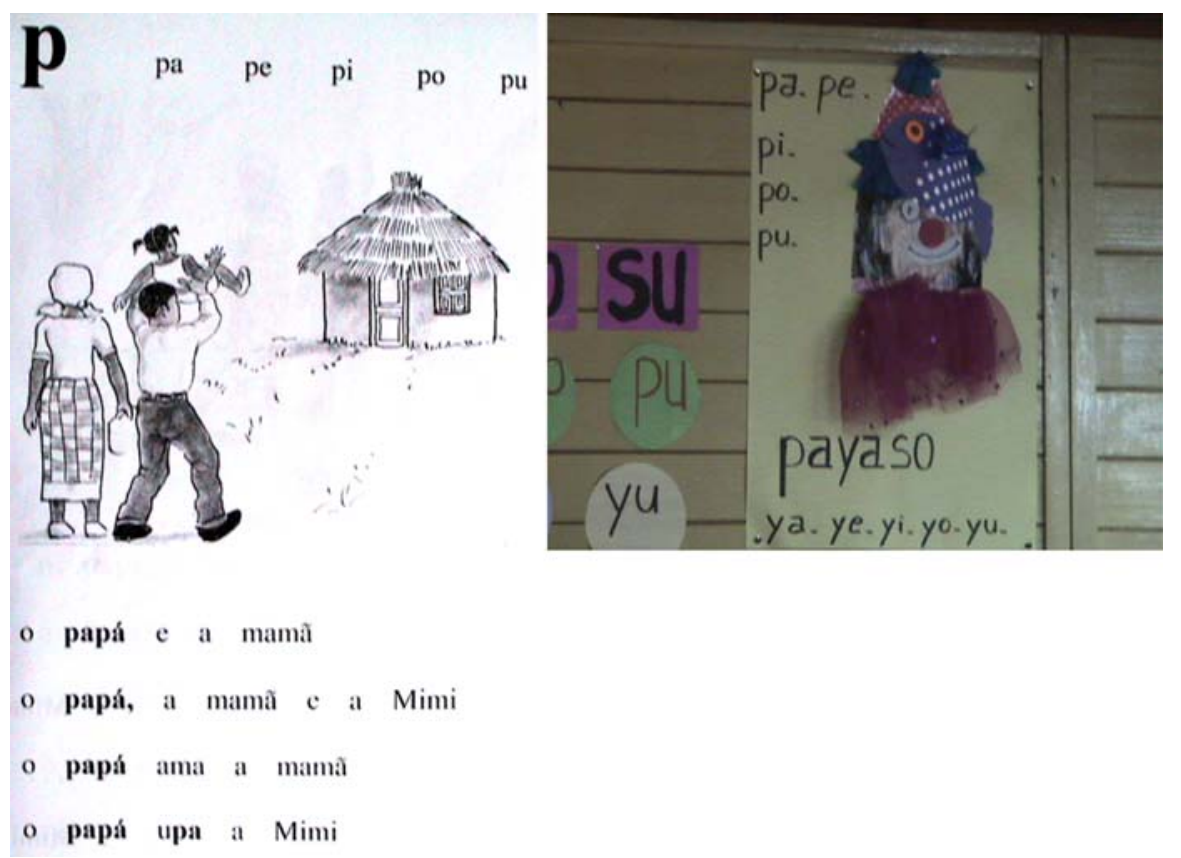

Source: Left: Textbook Eu Leio, by Frouke Dreisma (Mozambique: Progresso). Right: Syllables practice in rural Argentina (author's photograph).

needed on average to attain a speed of 45 words per minute. However, the experiences of literacy providers such as Pratham suggest that only about 90 hours of practice may be needed to bring students in most languages to the minimum reading speed. The prerequisites are use of instructional time for practice, feedback to students, potentially phonological awareness exercises, and explicit instruction in synthetic phonics (Figure 5).

\section{Goal: sixty words per minute for all}

The science that links reading to comprehension leads to a quantitative model of reading efficiency that has a simple and transparent monitoring indicator. This in turn makes it possible to establish goals and benchmarks for the early grades. By the end of grade 1, children should "crack the code" and read haltingly. By the end of grade 2, almost all students should read simple text fluently, that is at about 45-60 words per minute. A goal for the end of primary school (usually grade 6) might be a speed of 150 words per minute (see US norms in Table 2).

In each country and for each language, parsimonious ways must be found to teach reading. Teacher training and supervision institutions should plan 
on how to achieve this goal. Even syllabic scripts have high-frequency combinations that account for most common words. Practice is critical for automaticity. To increase the hours and opportunity of practice, textbooks and reading books should be available for students to take home, not just for reading at school. Small sums (available through school improvement grants) may be used to entice older students to spend time guiding younger children to read if their parents cannot do so. Reading books are needed, with students receiving explicit assignments to study and summarize them. Communities may be easily trained to recognize the signs of fluent reading and hold teachers accountable to this standard (Abadzi 2007).

To teach reading to classrooms full of disadvantaged students, there is a need for innovative research and development of methods. For example, a generic module could be developed to teach fundamental reading efficiently. Such a module should use the features known to be effective (such as letter combination analogies, phonological awareness, optimally spaced text based on perceptual research) and do so for various languages in a few important scripts (Latin, Arabic, Indian languages). Then the module could be tested against alternatives in important script-language combinations for efficiency given time use. To adjust curricula, it is also important to estimate the average number of engagement hours needed to reach 45-60 words per minute under various programs. Speed and efficiency of instruction are key in the schools of the poor, where students are constantly at risk of dropout.

\section{Writing and the role of working memory}

Much of the educational research has been focused on the more advanced aspects of writing, such as expression of ideas. However, writing depends on well-known memory aspects. When people write, they transfer messages that they hold in working memory to written symbols. If they write too slowly or take time to think how a word is spelled, they may forget the message they meant to convey. Incoherent writing may be at least partly due to transfer issues and a slow writing speed. It sounds iconoclastic, but perhaps there should be writing speed contests in schools.

Writing acquisition has not been researched as much as reading, and for some important questions the answers remain speculative. It makes good common sense that writing "deepens" reading acquisition by connecting the visual shapes to psychomotor circuits. Indeed, the brain's premotor area which plans movements becomes active during reading, so having children try to write letters while they are learning to recognize them might produce a multisensory representation of letters and 'deepen' learning (Szüchs and Goswami 2007).

Copying is a task that is widely used in many parts of the world, but its effects have not been researched extensively. Practice leads to fast and 
automatic writing, so it makes good sense for small children to copy passages and acquire psychomotor automaticity. But empirical observations in low-income schools suggest that children can make excellent letter reproductions without learning to read them. Even when they can decipher letters, the systematic practice of copying texts from the board (often due to a lack of textbooks) has dubious effects. Unless students write fast, their working memory probably cannot hold sentences copied verbatim long enough to be understood. Those who have low-level literacy do not even copy correctly; in Guinea, only $41-57 \%$ of words were copied correctly in grade 2 and $47-58 \%$ of phrases were copied correctly in grade 4 (Barrier et al. 1998). On the other hand, students who write fast enough to summarize ideas into notes are more likely to recall later the major points of lectures (Peper and Mayer 1978).

As mentioned earlier, some scripts have more complex spelling or use more and more intricately shaped letters (e.g., Nag 2003, 2007). These variables may affect the amount of time students take to write messages in them and thus the working memory available for transferring a message into print. Script issues deserve more research. What is more important in literacy acquisition of a population, fewer signs or less intricate patterns? Scripts are rarely reformed, but reading and writing instruction can greatly improve through targeted neurocognitive research.

\section{Cognitive neuroscience and definitions of literacy}

Much ink has been spilled over the years about the definition of literacy, but neuroscientific research has some new implications about it. Functionally literate are the people who can decode a message within the limits of their working memory. Literacy could also be defined as a function of activation of the occipito-temporal pathway in the brain, which is assessed through brain imaging.

Some other skills also depend on the neurocognitive aspects of literacy. Musical notation and sign language involve visual discrimination and automaticity through practice and could be considered "literacies". The ancient survival skills of tracking animal footprints on the ground may also use the same neurocognitive mechanisms. By contrast, the commonly used term "multiple literacies" goes beyond automaticity of visual patterns. It refers to interpretation of information presented through various media beyond the traditional 'reading and writing' definition of literacy (Larson 2006). Thus, it pertains to higher-order reasoning of people who are already automatic readers and is in some respects a misnomer. The "multiple literacies" term demonstrates the limited understanding of some educators about the neuropsychology of reading. 


\section{Numeracy as a literacy}

Arithmetic work in primary school involves the decoding and automatization of certain symbols and their spatial configurations, so it could be considered as a "literacy". The symbols are few and have explicit interpretations, so they are easily learned. Reading fluency is very important for arithmetic. Students need it to solve problems that involve narratives, and those who cannot read also cannot perform well in math. Fluent performance of various arithmetic actions results from practice and automaticity.

Numeracy is a complex function. Humans are born with the ability to do calculations that involve a very small number of items (around 3), so children usually can calculate using small numbers. Very important is the development of brain areas related to numeracy and the links among them. The same circuit that assesses whether 3 is greater than 5 also assesses whether a watermelon is bigger than a grape. Also, children build up their concept numbers linearly, through a mental number line. There is a strong link between preschoolers' mental representations of numbers and how well they do in school, so reinforcing the linear image (e.g., through the use of "chutes and ladders" game; Begley 2007) might strengthen children's early number sense. However neurocognitive research on numeracy is still underway, and there are few clear applications or benchmarks that schools can put to use.

\section{Improving learning outcomes - what to do next?}

The capacity of working memory in reading creates a paradox. Slower readers read less material but use up more working memory. They must make more effort to read and write, muster more attention, and may still lose part of the message. Children who read haltingly are probably functionally illiterate. They may puzzle out some phrases, but they cannot read or understand the volumes of text needed to learn the curricula. Since children cannot learn from textbooks until they become fluent readers, the effects of illiteracy may reverberate though secondary and higher education. Illiteracy translates into dropout, grade repetition, and a need for extra resources. The survivors may enter secondary school with a reading speed of 80 words per minute and second-grade knowledge and be unable to catch up over the years. Then universities in low-income countries must deal with students who lack the prerequisites to follow higher-level courses. Illiteracy in grades 1-2 creates inefficiencies that reverberate all through the educational system.

What to do? Reading rate benchmarks suggested by neurocognitive research are easy to operationalize and monitor. To improve them, there is a need to investing more in the lower grades. Students in grades 1-2 are likely to perform better if they have more time on task, smaller classes, and more experienced teachers. They could also get the help of older students paid small amounts to read with them. Educating marginalized and vulnerable 
children may have higher unit costs, but the increased investment on the lower grades will result in savings from repetition, dropout, and time wastage. Rather than focus on increasing the number of graduates, governments and donors might focus on learning efficiency: getting the largest possible number of literate school leavers.

The findings and implications of neurocognitive research are recent, and they have not been broadly disseminated to the educational community. Once they become better known and validated through experience, they may become more acceptable. With partial knowledge, some educators pose philosophical objections. The focus on fluency is often seen as retrograde and conservative, particularly for the poor. (Ironically, poor students need more explicit instruction to catch up in vocabulary, while the better-off students perform better and thus have spare time to spend on comprehension and more attractive activities.) One example was reaction in Peru: A reading study in that country (Abadzi et al. 2005) set off a high-level political storm about children's illiteracy but also an emotional reaction from some educators who felt that reading fluency was too behavioristic to fit in the educational ideals of the country. Other educators raise cultural concerns. It is hard for some people to comprehend that the information processing rules are the pretty much the same for the homo sapiens species, wherever people reside.

It helps to keep in mind that the more mechanistic aspects of reading are important mainly in the lower primary grades. Once fluency is achieved and basic skills are acquired, instruction should shift to comprehension, extraction of meaning from context, and all the joys of reading. It is the delay in fluency that often forces educators to focus on low-level boring tasks. The Education for All (EFA) aims to provide people with the ability to acquire information and make better decisions that lead to improved labor outcomes and quality of life.

Debates about reading may go on, but improving learning efficiency and outcomes is urgent. The year 2015 is approaching fast; the world must adopt more efficient learning methods or risk creating cohorts of illiterate dropouts and primary-school graduates. It is hoped that the insights from the frontier of cognitive neuroscience can become broadly adopted before EFA expire.

The ideas and opinions expressed in this work are those of the author and do not necessarily reflect the views of the World Bank.

\section{Notes}

1. The World Bank, the United States Agency for International Development, and the Research Triangle Institute organized a meeting of reading experts in Washington DC on Nov 2006. The expert panel agreed that 
reading fluency is indeed a desirable quality and that the fluency goals and monitoring indicators presented in this document are supported by the research.

2. Recent research suggests that working memory capacity is more limited than the research conducted in earlier decades, but it may appear longer because comprehension is facilitated by chunking and context (Cowan 2001). However, the traditional model of working memory capacity still helps explain the link between speed and comprehension.

3. People seem able to estimate accurately which letter combinations occur more and less often, even in languages they do not know well. So, it is possible to learn fluent reading without knowing a language; for example, many children learn to read sacred texts, such as Koranic Arabic, by monitoring sound frequencies. Thus fluent readers acquire phonological awareness and can write other languages with the script, such as African languages written in Arabic.

4. See www.educandojuntos.cl/. The Red Maestros de Maestros, Web site accessed in 2007: www.rmm.cl/index_sub.php?id_contenido=1128\&id_ seccion=310\&id_portal $=75$.

\section{References}

Abadzi, Helen. 2004. Education for All or Just for the Smartest Poor? Prospects 34: $271-289$.

Abadzi, H., L. Crouch, M. Echegaray, C. Pasco, and J. Sampe. 2005. Monitoring Education-for-All Outcomes Through Rapid Learning Assessments: A Case Study from Perú. Prospects 35: 137-156.

—. 2006. Adult Illiteracy, Brain Architecture, and Empowerment of the Poor. Adult Education and Development 65: 19-34.

2006. Efficient Learning for the Poor: Insights from the Frontier of Cognitive Neuroscience. World Bank: Directions in Development. Washington DC: World Bank.

2007. Instructional Time Loss and Local-Level Governance. UNESCO Prospects 137: 1, 3-16.

2007. Absenteeism and Beyond: Instructional Time Loss and Consequences. Policy research working paper series no: WPS4376. Washington, DC: World Bank.

Alloway, T. P., S. E. Gathercole, and S. J. Pickering. 2006. Verbal and visuo-spatial short-term and working memory in children: are they separable? Child Development 77: 1698-1716.

August, D., M. Carlo, M. Calderon, and P. Proctor. 2005. Development of Literacy in Spanish-Speaking English-Language Learners: Findings from a Longitudinal Study of Elementary School Children. IDA Perspectives.

Banerji, Rukmini, Madhav Chavan, and Usha Rane. 2004. Are we learning? A symposium on ensuring quality elementary education. Seminar 536 (http://www.indiaseminar.com/2004/536.htm). 
Barr, R., C. Blachowicz, C. Katz, and B. Kaufman. 2002. Reading Diagnosis for Teachers: An Instructional Approach (4th ed.). Boston, MA: Allyn and Bacon.

Barrier, Emilie, Sekou Fernández, Jeannot Saa Tinguiano, and Gononan Traore. 1998. Évaluation du système éducatif Guinéen. Sèvre: Centre International d' Ètudes Pédagogiques/Conakry: Cellule Nationale de Coordination de l'Évaluation du Système Éducatif.

Begley, Sharon. 2007. The Case for Chutes and Ladders. Newsweek, October 22: 51.

Breznitz, Z. 1997a. Effects of Accelerated Reading Rate on Memory for Text among Dyslexic Readers. Journal of Educational Psychology 89: 289-297.

— 1997b. Enhancing the Reading of Dyslexic Children by Reading Acceleration and Auditory Masking. Journal of Educational Psychology 89: 103-113.

Cossu, Guiseppe. 1999. The Acquisition of Italian Orthography. In: Learning to Read and Write: A Cross-Linguistic Perspective, ed. by M. Harris and G. Hatano. Cambridge, UK: Cambridge University Press.

Cowan, N. 2001. The Magical Number 4 in Short-Term Memory: A Reconsideration of Mental Storage Capacity. Behavioral and Brain Sciences 24: 87-185.

Crouch, Luis. 2007. Sample Size Considerations in Early Grade Reading Assessment. Washington, DC: Research Triangle Institute, unpublished report.

de la Colina, M. G., R. Parker, J. Hasbrouck, and R. Lara-Alecio. 2001. Intensive Intervention in Reading Fluency for At-Risk Beginning Spanish Readers. Bilingual Research Journal 25(4): 417-452.

Davidson, M., and J. Towner. 2005. Evaluating An Oral Reading Fluency Cut-Score to Identify Second Grade Children Who Are At-Risk for Reading Failure. Paper submitted for publication.

Cummins, J., M. Swain, K. Nakajima, J. Handscombe, D. Green, and C. Tran. 1984. Linguistic interdependence among Japanese and Vietnamese immigrant students. In: Communicative Competence Approaches to Language Proficiency Assessment: Research and Application, ed. by C. Rivera, 60-81. Clevedon, England: Multilingual Matters.

Dempster, Frank. 1988. The spacing effect: A case study in the failure to apply the results of psychological research. American Psychologist 43: 627-634.

Equipo de Orientación Educativa de Marbella. 2003. Evaluación de la velocidad lectora oral y análisis de la correlación de esta variable con la nota global de junio. Consejería de Educación y Ciencia. Junta de Andalucía.

Gathercole, Susan E., Susan J. Pickering, Camilla Knight, and Zoe Stegmann. 2004. Working memory skills and educational attainment: Evidence from national curriculum assessments at 7 and 14 years of age. Applied Cognitive Psychology 18: 1-16.

Hagtvet, B., and S. A. H. Lyster. 1998. Literacy Teaching in Scandinavia: Focus on Norway. In: The Encyclopedia of Language and Education, ed. by V. Edwards, 225-234. Dordrecht: Kluwer Academic Publishers.

- 2003. Spelling Errors of Good and Poor Decoders. In: Dyslexia in Different Languages: Cross-Linguistic Comparisons, ed. by N. Goulandris, 181-207. London: Whurr Publishers.

Hagtvet, B. E, T. Helland, and S. A. H. Lyster. 2005. Literacy Acquisition in Norwegian. In: Handbook of Orthography and Literacy, ed. by R. M. Joshi and P. G. Aron. Mahwah, NJ: Laurence Erlbaum. 
Hanushek, Eric A., and Ludger Woessmann. 2007. The Role of Education Quality in Economic Growth. World Bank Policy Research Working Paper 4122. Washington DC: World Bank.

Harris, M., and G. Hatano. 1999. Introduction: A Cross-Linguistic Perspective on Learning to Read and Write. In: Learning to Read and Write: A Cross-Linguistic Perspective, ed. by M. Harris and G. Hatano. Cambridge, UK: Cambridge University Press.

Hartley, M., J. Swanson, and V. Eric. 1986. Retention of Basic Skills among Dropouts from Egyptian Primary Schools. Working paper series report no: EDT40. Washington, DC: World Bank.

Hasbrouck, J., and G. A. Tindal. 2006. Oral Reading Fluency Norms: A Valuable Assessment Tool for Reading Teachers. The Reading Teacher 59: 636-644.

Kirschner, P. A., J. Sweller, and R. E. Clark. 2006. Why Minimal Guidance During Instruction Does Not Work: An Analysis of the Failure of Constructivist, Discovery, Problem-Based Experiential and Inquiry-Based Teaching. Educational Psychologist 41 (2): 75-86.

Korkman, Marit, Sarah L. Kemp, and Ursula Kirk. 2001. Effects of Age on Neurocognitive Measures of Children Ages 5 to 12: A Cross-Sectional Study on 800 Children from the United States. Developmental-Neuropsychology 20(1): 331-354.

LaBerge, D., and S. J. Samuels. 1974. Toward a theory of automatic information processing in reading. Congnitive Psychology 6: 293-323.

Larson, Joanne. 2006. Multiple Literacies, Curriculum, and Instruction in Early Childhood and Elementary School. Theory Into Practice 45: 319-329.

Ledesma, H. M. L., and R. Morris. 2005. Language Factors Influencing Early Reading Development in Bilingual (Filipino-English) Boys. The International Journal of Bilingual Education and Bilingualism 8(1): 1-19.

McCutchen, D., and V. W. Berninger. 1999. Those Who Know Teach Well: Helping Teachers Master Literacy-Related Subject Matter Knowledge. Learning Disabilities Research and Practice 14: 215-226.

McCutchen, D., R. D. Abbott, L. B. Green, S. N. Beretvas, S. Cox, N. S. Potter, T. Quiroga, and A. Gray. 2002. Beginning Literacy: Links Among Teacher Knowledge, Teacher Practice, and Student Learning. Journal of Learning Disabilities 35: 69-86.

Metcalf, Janet. 2006. Principles of Cognitive Science in Education. APS Observer 2006 19(3).

Moats, L. C., and B. F. Foorman. 2003. Measuring teachers' content knowledge of language and reading. Annals of Dyslexia 53: 23-45.

Nag, Sonali. 2007. Early Reading in Kannada: The Pace of Acquisition of Orthographic Knowledge and Phonemic Awareness. Journal of Research in Reading 30: 7-22.

Nag-Arulmani, Sonali. 2003. Reading Difficulties in Indian Languages. In: Dyslexia in Different Languages: Cross-Linguistic Comparisons, ed. by Goulandris Nata and Snowling Margaret. London: Whurr Publishers.

Nagy, Zoltan, Helena Westerberg, and Torkel Klingberg. 2004. Maturation of white matter is associated with the development of cognitive functions during childhood. Journal of Cognitive Neuroscience 16(7): 1227-1233. 
Norton, Elizabeth S., Ioulia Kovelman, and Laura-Ann Petitto. 2007. Are there Separate Neural Systems for Spelling? New Insights into the Role of Rules and Memory in Spelling from Functional Magnetic Resonance Imaging. Mind, Brain, and Education 1: $48-59$.

Pelli, Dennis and Katharine Tillman. 2007. Parts, Wholes, and Context in Reading: A Triple Dissociation. PLoS ONE, August 2007, e 680.

Pelli, D. G., C. W. Burns, B. Farell, and D. C. Moore-Page. 2006. Feature detection and letter identification. Vision Research 46(28): 4646-4674.

Peper, R. J., and R. E. Mayer. 1978. Note-Taking as a Generative Activity. Journal of Educational Psychology 70: 514-522.

Pérez Villar, J.. 1996. ¿Cómo lee mi paciente?: Contribución a la metodología del examen directo en psiquiatría de niños. Revista Cubana de Pediatría 68(3): 201-210.

Riedel, Brant. 2007. The Relation Between DIBELS, Reading Comprehension, and Vocabulary in Urban First-Grade Students. Reading Research Quarterly 42: 546-567.

Seymour, P., H. K. M. Aro, and J. M. Erskine. 2003. Foundation Literacy Acquisition in European Orthographies. British Journal of Psychology 94(2): 143-174.

Shaywitz, Sally. 2003. Overcoming Dyslexia. New York: Alfred Knopf.

Snow, C. E., M. Susan Burns, and P. Griffin (eds.). 1998. Preventing Reading Difficulties in Young Children. Committee on the Prevention of Reading Difficulties in Young Children. Washington DC: National Research Council.

Spear-Swerling, L., and P. Brucker. 2004. Preparing Novice Teachers to Develop Basic Reading and Spelling Skills in Children. Annals of Dyslexia 54: 332-364.

Spratt, J., and M. Tamba. 2005. Extending the Partnership: Involving Practitioners in the Data Analysis and Interpretation Process. Paper Presented March 23 at the Annual Conference of the Comparative and International Education Society, Palo Alto, California.

Szucs, Dénes, and Usha Goswami. 2007. Educational neuroscience: Defining a new discipline for the study of mental representations. Mind, Brain, and Education 1:3: 114 127.

Tan, A., and T. Nicholson. 1997. Flashcards Revisited: Training Poor Readers to Read Words Faster Improves their Comprehension of Text. Journal of Educational Psychology 89: 276-288.

UNESCO. 2002-2006. Education for All Global Monitoring Reports. Paris: UNESCO.

Wimmer, H., K. Landerl, and U. Frith. 1999. Learning to read German. In: Learning to Read and Write: A Cross-Linguistic Perspective, ed. by M. Harris and G. Hatano, 4-50. Cambridge University Press: Cambridge, UK.

World Bank 2006. From Schooling Access to Learning Outcomes: An Unfinished Agenda. Washington DC: World Bank, Independent Evaluation Group.

\section{The author}

Helen Abadzi is a Greek educational psychologist and a senior evaluation officer at the Independent Evaluation Group of the World Bank. She monitors cognitive science and 
memory research in search for applications that may improve learning outcomes in lowincome schools. She is a polyglot, so she understands first-hand the reading issues pertaining to various languages and scripts.

Contact address: Independent Evaluation Group, Mail Stop I9904, World Bank, Washington, DC 20433, USA. E-mail: habadzi@worldbank.org. 
Copyright of International Review of Education is the property of Springer Science \& Business Media B.V. and its content may not be copied or emailed to multiple sites or posted to a listserv without the copyright holder's express written permission. However, users may print, download, or email articles for individual use. 